\title{
The Efficacy of Using Pair Work Technique in Teaching Conditional Sentences to Indonesian English as Foreign Language (EFL) Students
}

\author{
Soleman Dapa Taka \\ sdapataka@gmail.com \\ Universitas Nusa Cendana, Kupang, NTT, Indonesia
}

Received: 27 November 2020 Accepted: 01 December 2020

DOI: $10.24256 /$ ideas.v8i2.1690

\begin{abstract}
This research aims at finding out the efficacy of using the pair work technique in teaching grammar especially the conditional sentences to Indonesian English as Foreign Language (EFL) students. The main question of this research: Is the use of the pair work technique effective in teaching conditional sentences to Indonesian EFL students?. The research can be an addition to the persisting teaching grammar of English particularly the conditional sentences through the use of the pair-work technique. This research was conducted at the tenth-grade students at SMA Kristen Mercusuar Kupang, an Indonesian High School. The total number of samples was 25 students. The research used a pre-experimental method with a pre-test and post-test design. The pre-test was given to find out the basic ability of the students in mastering conditional sentences and the post-test given to find out the students' improvement in mastering conditional sentences after giving the treatment by using of pair work technique. The findings show that using the pair work technique is effective in teaching conditional sentences to Indonesian EFL students. It is supported by the result of the significance test through SPSS 20 program that the $\mathrm{P}$ was 0.00. Therefore, it is recommended to use the pair work technique in developing students' competence in mastering conditional sentences l of Indonesian EFL students.
\end{abstract}

Keywords: Indonesia EFL students; pair work technique; teaching conditional sentences 


\section{Introduction}

Grammar is one of materials which are difficult for the students. Especially the students of senior high school. So, many kinds' materials in grammar that student gets in the high school as tenses, conjunction, preposition, causative, and many others. One of the material in grammar that always we find in daily life is conditional. Students of senior high school get conditional sentence in the second grade. As the writer knows, conditional sentence is always found in daily speaking, in writing, in fact in reading. In grammar, conditional sentences are sentences discussing factual implications or hypothetical situations and their consequences languages use a variety of conditional constructions and verb forms (such as the conditional mood) to form these kinds of sentences. In addition, Conditional sentences or "if sentences" are sentences in English that explain that a thing depends on other things or a sentence that is conditional.

When the writer did observation in SMA Kristen Mercusuar Kupang, he found that some of the students do not know the use of conditional sentence in daily life and she found that the students still didn't understand about the material. Even though the students always learn it before the writer did observation there, they still confused about it.

To solve these problems, the English teacher try to apply various teaching techniques, or the teacher has to create class atmosphere of how to encourage student's speaking ability. A teacher plays an important role in teaching and learning process in classroom activities. He or she is responsible to determine the aim of teaching and has to create favorable situation in motivation the students to study. To teach successfully, an English teacher has to use certain strategies to make the students understand the lesson.one of the techniques that can be used by a teacher in teaching conditional sentences namely pair work technique.

Harmer (2001:207) as cited in Mulya (2016:79) defines pair work as a way of increasing students participation and language use. This technique can be used in enormous number activities whether speaking, reading, or writing. Pair work is one technique of Communicative Language Teaching (CLT). It requires students to be paired and cooperate to solve task that is given by teacher. Then, Richard and Schmidt (2002:381) in Zohairy (2014:51) states that Pair Work is learning activity which involve students to work together in pair. Lightbown and Spada (1999) in Mulya (2016:79) state that in an interactive environment students can advance to higher level of knowledge and performance than they have to work individually. So, this pair work technique is the appropriate technique that is used to improve students' speaking, because activity in pair work technique requires students to interact with their pair. Beside it will be easier to be controlled by teacher and all of the students will be active as well.

There are three stages in implementing Pair Work Technique in class according to Harmer (2001:122-124): (1) Before: in this stage, teacher needs to follow engage instruct-initiate sequence. It is to give understanding to the students about 
The Efficacy of Using Pair Work Technique in Teaching Conditional Sentences to Indonesian English as Foreign Language (EFL) Students

what they are going to do and when they have to finish their task. (2) During: while students are working in group, teacher can keep an eye on what happening and decide whether need to approach students or not. (3) After: teacher gives feedback after students finish their work.

According to Harmer (1991: 116) pair group have the following advantages:

1. it dramatically increases the amount of speaking time any one student gets in the class

2. It allows students to work and interact independently without the necessary guidance of the teacher, thus promoting learner independence.

3. It allows teacher time to work with one or two pairs while the other students continue working.

4. It recognizes the old maxim that "two heads are better than one", and in promoting cooperation helps the classroom to become a more relaxed and friendly place. If we get students to make decisions in pairs (such as deciding on the correct answer to questions about reading text), we allow them to share responsibility rather than having to bear the whole weight themselves.

5. It is relative quick and easy to organize.

To make pair activities successful in the classroom activity the teacher must pay attention to some procedures namely:

a. He can prepare for the pair of establishing what the questions and answer should be. He can also demonstrate the pair activity through asking question around the class or through getting one pair of the student to ask and answer in the front of the class. The students knew exactly what to do.

b. He can be active in starting the pair activity, instead of saying "work in pairs". He can also check, if everyone has a partner and starts working in pairs. This will be very important if the class is not accustomed to pair work.

c. During activity, he can move quickly around the class to check that the students are talking and to see if they have finished

d. Instead of writing for everyone the finish the activity, there will be no chance for the students to get bored and start talking about other things.

e. After the students discuss in their pair, he/she can ask some points what they have done, or ask a few points of repeat their conversation in front of the class.

Based on the situation the researcher is interested in conducting a research under the topic "the efficacy of using pair work technique in teaching grammar especially the conditional sentences to Indonesian English as Foreign Language (EFL) students" , as a result in real situation he does not find an adequate and appropriate strategy teaching conditional sentences in SMA Kristen Mercusuar Kupang, an Indonesian High School it may be caused by most English teachers still teach by using conventional method in teaching grammar. Therefore, it is very 
important to provide an alternative technique to improve student; it is assumed that using pair work technique might for improve the students' ability in mastering grammar especially conditional sentences.

From the background of the study, the researcher formulated the research questions such as below: Does the use pair group improve the ability in using conditional sentence of second year students of SMA Kristen Mercusuar Kupang,?. Then, the researcher formulates the objective of the research as follows: To find out the effectiveness of using pair group in improving the ability in using conditional sentence at second year students of SMA Kristen Mercusuar Kupang,.

This research is expected to e useful information for teacher and the students about teaching conditional sentence by the students through pairs group. Also it expected to be a reference for the next researcher who wants to do a research about conditional sentences. The scope of the research is to know what teaching conditional sentence of SMA Kristen Mercusuar Kupang, at the second year students through pair group. Then it is limited for knowing the factor hamper the students in understanding conditional sentence in three patterns. They are future conditional, present conditional, and past conditional.

There are some previous studies related to the research. They are: Arma (2004) in her thesis is entitled " Reading Comprehension Ability of the Second Year Students Of SMP Kristen Palopo" reveated that student sometime fail to graph what they are reading. Some student might have good pronunciation and can read fast, but they were unable to retell, or summarized what they have read. She also found out that reading always involves thinking process beside of visual interpretation, in spread by this finding, the researcher is curious to apply the same research method to find out whether or not reciprocal teaching can make the student be easier to comprehend reading text. Minati (2009) in her thesis entitled " Increasing Students' reading skill at the second year SMA N 1Baebunta Through Anecdotes". The writer down her thesis from the table show that the mean score of the students pre-test was 6.0 and mean score of the post test was 7.0

Based on the previous study written by Mulya (2016) that find pair work technique is effective to improve students' speaking performance. Next, Susanto (2013) through his thesis states that pair work technique can improve students' competence. Also, Baleghizadeh \& Farhesh (2014) through their journal conclude that pair work can improve students' motivation. These studies are enough to proof that pair work technique are able to improve not only students' speaking ability but also students' motivation. So based on the previous studies, the writer chooses pair work technique to improve students' ability in mastering conditional sentences. By using the technique the students will be able to learn effectively. It is because they can work cooperatively to complete task that is given by teacher 
The Efficacy of Using Pair Work Technique in Teaching Conditional Sentences to Indonesian English as Foreign Language (EFL) Students

\section{Method}

In this research, the researcher applied a pre-experimental method. Pre-experimental design used pre-test and post-test where pre-test was held before treatment and post-test after treatment.

The design of the research is as follow:

$\mathrm{O}_{1} \quad \mathrm{X} \quad \mathrm{O}_{2}$

Where:

$$
\begin{aligned}
& \mathrm{O}_{1}=\text { pre-test } \\
& \mathrm{X}=\text { treatment } \\
& \mathrm{O}_{2}=\text { post-test }
\end{aligned}
$$

(Best 1997:103)

The population of this research was the tenth grade students at SMA Kristen Mercusuar Kupang, an Indonesian High School. In determining the sample of this research. The researcher took 24 students as sample of this research. The writer used grammar test to measure the students' ability in mastering conditional sentence. Before and after giving treatment writing involves

The data was collected by using the procedure below:

1. Giving Pre-test

Firstly, the researcher introduced himself to the students and explained purpose of her coming in their class. The researcher gave pre-test to the students to measure the skill of the students before giving treatment.

2. Giving Treatment

The researcher conducted the treatment to the students for sixth meetings by using pair work technique in teaching conditional sentences. the steps as follows: (1) Before: in this stage, teacher needs to follow engage instruct-initiate sequence. It is to give understanding to the students about what they are going to do and when they have to finish their task. (2) During: while students are working in group, teacher can keep an eye on what happening and decide whether need to approach students or not. (3) After: teacher gives feedback after students finish their work.

\section{Giving Post-test}

The students were given the same activity in the pre-test after the treatment. The researcher gave grammar test and asked the students to answer. It aimed at finding out the students'ability in writing skill after giving treatment..

In analyzing data, the researcher giving score to the students based on the result of their reading test in pre test and post test. The last step of the data analysis was the hypothesis testing. The hypothesis was tested by using inferential statistics. In this case, the researcher used t-test (testing of significance) for paired sample t-test, that is, a test to know the significance difference between the result of students' mean score in pretest and post test. 


\section{Results}

From the result data analysis, shows that the mean score of the students pretest was 40 and the mean score of posttest was 75 It means that using reciprocal teaching technique in teaching reading can enhance the students' achievement especially for the students' reading skill.

From the statistical analysis, the researcher concludes that there is a significant difference between pretest and posttest in enhancing the students' reading ability through reciprocal teaching technique as a way to deliver learning material. reciprocal teaching technique is effective in enhancing the students' reading ability. Based on the describing above, the researcher concludes that one of important point that teacher should accommodate he/she should give full the attention especially in reading skill. Therefore, in teaching writing one of technique that the teacher may use this technique in teaching, especially in writing or constructing ideas is greatly expected to make the students easier in generating and expressing their idea in different mode and sense.

After calculating the result of the students' pretest, the mean score and standard deviation of both groups are presented in following table:

\begin{tabular}{lll}
\hline & Pretest & Posttest \\
\hline Mean & 40 & 75 \\
\hline Standard dev. & 8.30 & 10.49 \\
\hline Max & 43 & 64 \\
\hline Min & 21 & 37 \\
\hline
\end{tabular}

The data shows the mean score of the students pretest was 40 and the mean score of posttest was 75. Standard deviation of pretest was 8.22 and the standard deviation of posttest was 11.27. It means that using reciprocal teaching technique in teaching reading can enhance the students' achievement in reading.

The hypothesis was tested by using inferential statistics. In this case, the researcher used t-test (testing of significance) for paired sample t-test, that is, a test to know the significance difference between the result of students' mean score in pretest and posttest.

Assuming that the level of significance $(\alpha)=0.05$, the only thing which is needed; the degree of freedom $(\mathrm{df})=\mathrm{N}-1$, where $\mathrm{N}=25$, then the t-test is 10.81 $\mathrm{P}$ is 0.00

From the analysis, the researcher concluded that there was a significant difference between pretest and posttest in enhancing the students' grammar ability trough pair work technique as a way to deliver learning process. The result of statistical analysis for level of significance $(p=0.05)$ with degree of freedom $(\mathrm{df})=$ $\mathrm{N}-1$, where $(\mathrm{N})=25, \mathrm{df}=24$. The probability value was smaller than $\alpha(0.00<0.05)$. it indicated that the alternative hypothesis (H1) was accepted and the null hypothesis (H0) was rejected. It means that pair work technique is effective in 
The Efficacy of Using Pair Work Technique in Teaching Conditional Sentences to Indonesian English as Foreign Language (EFL) Students

enhancing the students' grammar ability especially conditional sentences.

\section{Discussion}

Based on the result of data analysis, the researcher found out that the use of pair work technique is effective in developing students' competence in grammar skill at the tenth grade students at SMA Kristen Mercusuar Kupang. Actually, there some techniques that we can use to teach speaking but the researcher using parallel writing technique, moreover the application of think pair share strategy gave good effect in enhancing the students' skill in reading..

Based on the data collected, using pair work technique in teaching conditional sentences can enhance the students' achievement. It was proved by students' score on the grammar test. All students' score was improved after conducting the treatment through pair work technique. The result of this research is supported by Harmer (2001:207) as cited in Mulya (2016:79) defines pair work as a way of increasing students participation and language use. This technique can be used in enormous number activities whether speaking, reading, or writing.

This research has shown that pair work can increase the students' ability in mastering conditional sentences. So, in teaching conditional sentence, the students should be in pairing work that will be a useful situation where the students can share their knowledge and support their pair in mastering conditional sentences in English.

\section{Conclusion}

The researcher concludes that the use of pair work technique is effective in developing students' competence in mastering skill at the tenth grade students at SMA Kristen Mercusuar Kupang, NTT. It was proven by there was a significant difference between the students' mean score of pretest and posttest. The result of statistical analysis for level of significance $(p=0.05)$. The probability value was smaller than $\alpha(0.00<0.05)$. it indicated that there is significant differences between the result of pre-test and post-test after giving treatment in improving students' competence in mastering conditional sentences through applying pair work technique to the tenth grade students at SMA Kristen Mercusuar Kupang NTT.

\section{References}

Astuti, H. (2017). The Influence of Using Dictogloss Technique towards Students ' Writing Ability in Analytical Exposition. State Islamic University of Raden Intan Bandar Lampung.

Baleghizadeh, S., \& Farhesh, S. (2014). The Impact of Pair Work on EFL Learners ' Motivation 1. MEXTESOL Journal, 38(3), 1-11.

Brown, G., \& Yule, G. (1983). Discourse Analysis. New Delhi: Cambridge University Press. Harmer, J. (2001a). How to Teach English (7th ed.).

Djalinus, S. 1977. Modern English Grammar. Jakarta. Cv Simplex Percetakan ESBE 
Gay. L. R. 1981. An Education Research. USA: Florida Universiry Press.

Gay. L. R. 1981. Educational Research: Competences for Analysis and application (2nd edition) USA: Florida International University.

Harlow: Pearson Education Limited. Harmer, J. (2001b). The Practice of English Language Teaching (3rd ed.). Harlow: Pearson Education.

Lukman, L. (2019). Implementing The Hidden Curriculum in EFL Classroom. IDEAS: Journal on English Language Teaching and Learning, Linguistics and Literature, 7(2). doi:https://doi.org/10.24256/ideas.v7i2.1043

Mubarok, H. (2015). Research in Language Education: An Introduction for Beginners. (H. Mubarok, Ed.) (1st ed.). Jogjakarta: Lingkar Media.

Mubarok, H., Effendi, D. E., \& Sofiana, N. (2016). Cooperative Integrated Reading and Composition (CIRC) - Based Interactive CD in Teaching Reading. Journal of Language

Mulya, R. (2016). Teaching Speaking by Applying Pair Work Technique. English Education Journal, 1, 74-86. Noprianto, E. (2017). Student 's Descriptive Text Writing in SFL Perspectives. IJELTAL (Indonesian Journal of English Language Teaching and Applied Linguistics), 2(1), 65- 81. https://doi.org/10.21093/ijeltal.v2i1.53

M. Echols. John. Sadily Hasan. (1989). Kamus Inggris Indonesia. Jakarta PT. Gramedia

Rosmini. (2008). The Ability of the Second Year Students of SMA Negeri 1 Walenrang in Learning Conditional Sentence thesis. Universitas Cokroaminoto Palopo

Harbia, (2007). Developing the Speaking Skill of the Eleventh Class Students of SMA Negeri 3 Unggulan Palopo through Pair Activities. thesis Universitas Cokroaminoto Palopo.

Haryono, R, (2002). Complete English grammar. Surabaya. Gita Media Press.

Lado. MJ. (2007). Complete English grammar. Surabaya: Gita media press.

Manser, M. H. (1995). Oxford Learners Pocket Dictionary. Hongkong Oxford University Press.

Morris, W. (1981). The heritage dictionary of American English Language. Boston. Houghtn and mif. Flin. Company.

Sidayati. (2009). The difficulties faced by the second year students at SMA Neg. 1 Bosso in using conditional sentence. Cokroaminoto University Palopo.

Sa'idah, N. (2017). Buku Ajar Statistik Penelitian: Teori, Perhitungan Manual dan Aplikasi SPSS (1st ed.). Yogyakarta: Diandra Kreatis.

Samad, I. A., Bustari, A., \& Ahmad, D. (2017). The Use of Podcasts in Improving Students ' Speaking Skill. Journal of English Language and Education, 3(2), 97-111.

Sukardi. (2015). Metodologi Penelitian Pendidikan: Kompetensi dan Praktiknya (14th ed.). Jakarta: PT Bumi Aksara. Susanto, R. E. (2013).

Taka, S. (2020). The Efficacy of Using Reciprocal Teaching Technique in Teaching Reading to Indonesian English as Foreign Language (EFL) Students. IDEAS: 
Soleman Dapa Taka

The Efficacy of Using Pair Work Technique in Teaching Conditional Sentences to Indonesian English as Foreign Language (EFL) Students

Journal on English Language Teaching and Learning, Linguistics and Literature, 8(1), 197 - 206. doi:https://doi.org/10.24256/ideas.v8i1.1345

Thompson M. (1986). A Practical English grammar. Fourth edition. London. Oxford University Press.

Zohairy, S. (2014). Effective Pairwork Strategies to Enhance Saudi Pre-Intermediate College Students ' Language Production in Speaking Activities, European Scientific Journal 10(2), 50-63. 